\title{
Cholangiocarcinoma in Patients with Crohn's Disease
}

\author{
Tarek Debs, Isabella Reccia*, Imad El-Hajj, Ziad El-Rassi \\ Division of General and Visceral Surgery, Saint George Hospital University Medical Centre, Beirut, Lebanon \\ Email: ${ }^{*}$ isabella.reccia@unica.it
}

Received 16 November 2014; revised 10 December 2014; accepted 22 December 2014

Academic Editor: Sibu P. Saha, University of Kentucky, USA

Copyright (C) 2015 by authors and Scientific Research Publishing Inc.

This work is licensed under the Creative Commons Attribution International License (CC BY).

http://creativecommons.org/licenses/by/4.0/

(c) (i) Open Access

\begin{abstract}
Cholangiocarcinoma is an uncommon malignancy that increases with age. Cholangiocarcinoma has been linked to inflammatory bowel disease, and a relationship between inflammatory bowel disease, anti-tumour necrosis factor alpha antibody (Infliximab) and cholangiocarcinoma has been suggested. Although cholangiocarcinoma is usually associated with ulcerative colitis, recently more cases are being seen in association with Crohn's disease. The risk of cancer in patients treated with Infliximab has been discussed, and whether Infliximab is associated with an increased risk of cholangiocarcinoma is not clear. Cholangiocarcinoma is an uncommon malignancy and it is difficult to establish a clear correlation with Infliximab treatment. A large number of reports are needed to further address these issues.
\end{abstract}

\section{Keywords}

Cholangiocarcinoma, Crohn's, Inflammatory Bowel Disease, Infliximab

Cholangiocarcinoma is a malignant tumour arising at any portion of the biliary tree, divided into intrahepatic (peripheral) or extrahepatic [1] [2]. The distinction is important, since epidemiology, natural history and pathology differ significantly [1] [3]. Cholangiocarcinoma is an uncommon malignancy that increases with age, with most cases occurring in patients over 65 [4]. Despite the decline in the incidence of extrahepatic cholangiocarcinoma, the incidence of and mortality from intrahepatic cholangiocarcinoma has increased [5]. Cholangiocarcinoma is characterized by bad prognosis and poor response to therapies [1].

Few years ago, a 30-year-old man with a long history of moderate Crohn's disease was operated on at our surgical department for a large intrahepatic cholangiocarcinoma (Figure 1) and died from the disease one

${ }^{*}$ Corresponding author.

How to cite this paper: Debs, T., Reccia, I., El-Hajj, I. and El-Rassi, Z. (2015) Cholangiocarcinoma in Patients with Crohn's Disease. Journal of Cancer Therapy, 6, 21-24. http://dx.doi.org/10.4236/jct.2015.61003 
year later. He was treated with Azathioprine along with Infliximab for a short period of time. An induction regimen of 3 single-dose infusions of $5 \mathrm{mg}$ per $\mathrm{kg}$ of Infliximab at 0 , 2, and 6 weeks was used. Patient slightly improved but 3 months later developed painless obstructive jaundice and was diagnosed with cholangiocarcinoma.

The introduction of Infliximab has offered new treatment options in patients with Crohn's disease and changed disease outcome [5]. The risk of cancer after anti-TNF therapy is controversial [6]-[8]. However, it is difficult to prove a link between exposure and tumour development in these patients, since they may already be predisposed to cancer as a consequence of their underlying disease [9].

The correlation between Infliximab therapy and the development of cholangiocarcinoma in our patient was claimed. Liver function disorders were excluded before treatment. However, dimension at diagnosis suggested that the tumour was probably already present when Infliximab was administered. In this case, cholangiocarcinoma is likely a complication of Inflammatory Bowel Disease rather than of Infliximab infusion. It could be questioned whether immunosuppression might have increased the rate of tumour growth in our patient. Due to the liver toxicity of Infliximab and the risk of hepatic and biliary complications in Crohn's patients, liver function and imaging should always be carefully evaluated before Infliximab administration [10]. Cholangiocarcinoma is an uncommon but know extra-intestinal cancer complicating Inflammatory Bowel Disease [11]. Patients with Inflammatory Bowel Disease have a four-fold increased risk of developing cholangiocarcinoma, especially when they suffer from Ulcerative Colitis [12]. To our knowledge, only five studies in the literature reported an association between cholangiocarcinoma and Crohn's disease, with a total number of 9 cases (see Table 1) [13]-[17]. Most patients were female, young, and with a long duration of the disease before development of cholangiocarcinoma, with a severe prognosis and low survival. Tumour location was prevalently the hilum. Infliximab therapy was only recorded in one case, in association with Azathioprine and previous long course of Metronidazole, which safety is also controversial [17].

The risk of cancer in patients treated with Infliximab has been discussed, and whether Infliximab is associated

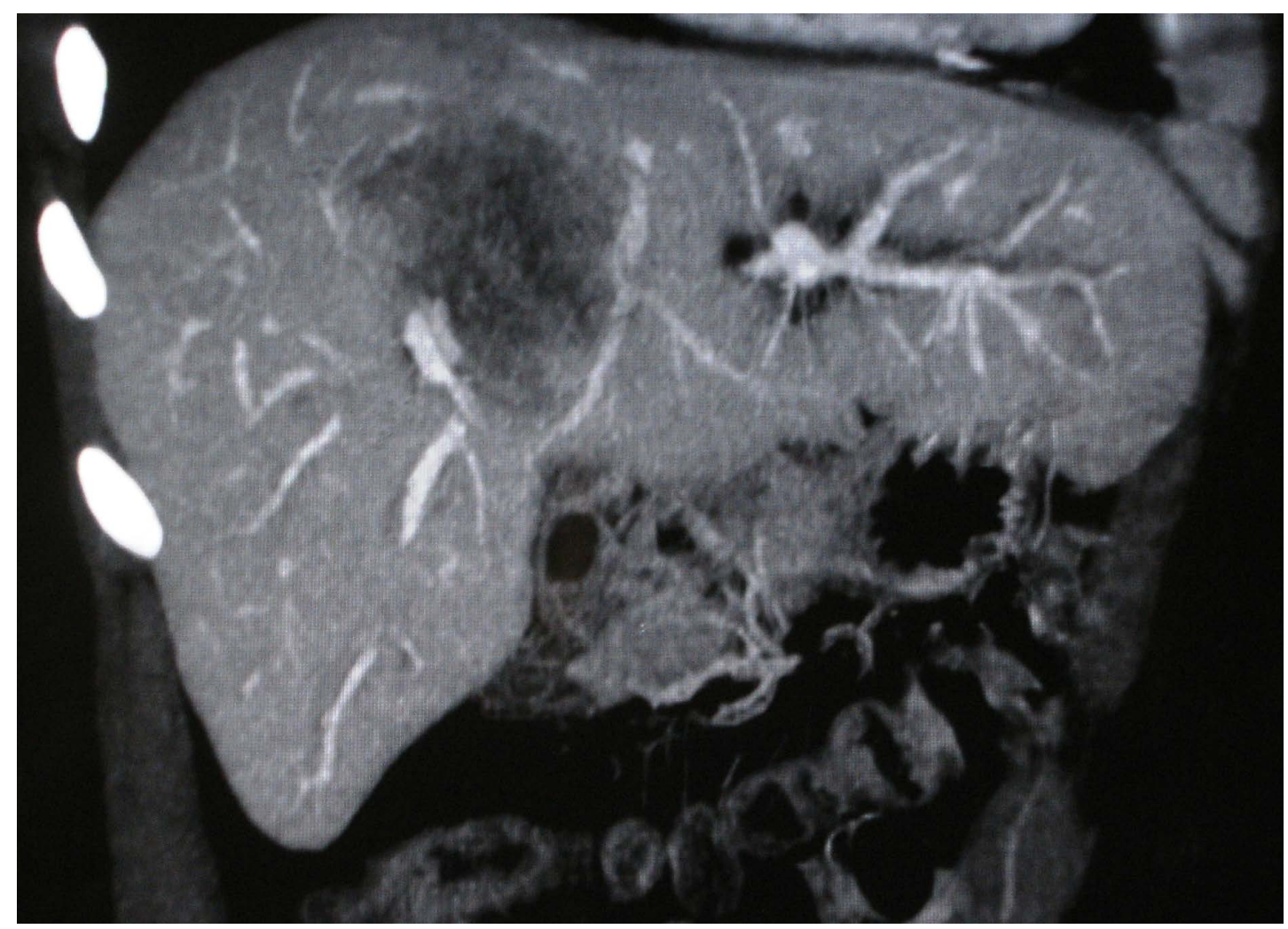

Figure 1. CT scan showing in segment 8 and 4 a large liver mass measuring $60 \times 85 \mathrm{~mm}$ in the axial axes and about $9 \mathrm{~cm}$ in height, associated with multiple smaller peripheral lesions and responsible for an important dilatation of bile ducts. 
Table 1. Patient characteristics from the review of the literature.

\begin{tabular}{|c|c|c|c|c|c|c|c|c|c|}
\hline Reference & $\begin{array}{l}\text { Number } \\
\text { of patients }\end{array}$ & Sex & $\begin{array}{c}C^{\mathbf{a}} \\
\text { (age at } \\
\text { diagnosis, } \\
\text { years) }\end{array}$ & $\begin{array}{l}\text { Location } \\
\text { of } C D^{\mathbf{a}}\end{array}$ & $\begin{array}{c}\mathrm{CD}^{\mathbf{a}} \\
\text { (age at } \\
\text { diagnosis, } \\
\text { years) }\end{array}$ & $\begin{array}{l}\text { Treatment } \\
\text { of } C^{\mathbf{a}}\end{array}$ & $\begin{array}{l}\text { Mortality } \\
\text { for } \text { CCA }^{\mathrm{b}}\end{array}$ & $\begin{array}{c}\text { Disease } \\
\text { duration } \\
\text { (years) }\end{array}$ & $\begin{array}{l}\text { Location } \\
\text { of tumor }\end{array}$ \\
\hline $\begin{array}{c}\text { Berman } \\
(1980)\end{array}$ & 1 & F & 30 & Small bowel & 43 & N/A & N/A & 13 & Hilar \\
\hline $\begin{array}{l}\text { Krause } \\
(1985)\end{array}$ & 1 & M & 10 & N/A & 31 & $\mathrm{MT}^{\mathrm{d}}$ & N/A & 21 & N/A \\
\hline $\begin{array}{l}\text { Altaee } \\
(1991)\end{array}$ & 4 & F & N/A & N/A & $57 \pm 17$ & N/A & N/A & 8.5 & Hilar \\
\hline $\begin{array}{l}\text { Choi } \\
\text { (1994) }\end{array}$ & 1 & F & 27 & N/A & 57 & N/A & YES & 30 & Hilar \\
\hline $\begin{array}{l}\text { Biancone } \\
\text { (2006) }\end{array}$ & 1 & M & 25 & N/A & 48 & $\mathrm{MT}^{\mathrm{d}}+\mathrm{AZA}^{\mathrm{e}}+\mathrm{IFX}^{\mathrm{f}}$ & YES & 23 & N/A \\
\hline $\begin{array}{l}\text { Present } \\
\text { report } \\
(2013)\end{array}$ & 1 & M & 20 & Right colon & 30 & $\mathrm{AZA}^{\mathrm{e}}+\mathrm{IFX}^{\mathrm{f}}$ & YES & 10 & Intrahepatic \\
\hline Summary & 9 & $6 F / 3 M$ & $\begin{array}{c}\text { Range } \\
10-48.5\end{array}$ & - & $\begin{array}{l}\text { Range } \\
30-57\end{array}$ & - & & $\begin{array}{l}\text { Range } \\
10-30\end{array}$ & - \\
\hline
\end{tabular}

Abbreviations: ${ }^{a}$ CD: Crohn’s Disease; ${ }^{b} C C A$ : Cholangiocarcinoma; N/A: Not applicable; ${ }^{\mathrm{d}}$ MT: Metronidazole; ${ }^{\mathrm{e}} \mathrm{AZA}$ : Azathioprine; ${ }^{\mathrm{f}} \mathrm{IFX}$ : Infliximab.

with an increased risk of cholangiocarcinoma is not clear. Possible correlation of Infliximab administration and cholangiocarcinoma deserves more accurate designed studies, large case series, than single case reports.

\section{References}

[1] Bragazzi, M.C., Cardinale, V., Carpino, G., Venere, R., Semeraro, R., Gentile, R., Gaudio, E. and Alvaro, D. (2012) Cholangiocarcinoma: Epidemiology and Risk Factors. Translational Gastrointestinal Cancer, 1, 21-32.

[2] Blechacz, B., Komuta, M., Roskams, T., Gores, G.J., et al. (2011) Clinical Diagnosis and Staging of Cholangiocarcinoma. Nature Reviews Gastroenterology \& Hepatology, 8, 512-522. http://dx.doi.org/10.1038/nrgastro.2011.131

[3] Patel, T. (2011) Cholangiocarcinoma-Controversies and Challenges. Nature Reviews Gastroenterology \& Hepatology, 8, 189-200. http://dx.doi.org/10.1038/nrgastro.2011.20

[4] Carriaga, M.T. and Henson, D.E. (1995) Liver, Gallbladder, Extrahepatic Bile Ducts, and Pancreas. Cancer, 75, 171190. http://dx.doi.org/10.1002/1097-0142(19950101)75:1+<171::AID-CNCR2820751306>3.0.CO;2-2

[5] Shaib, Y.H. and El-Serag, H.B. (2004) The Epidemiology of Cholangiocarcinoma. Seminars in Liver Disease, 24, 115125. http://dx.doi.org/10.1055/s-2004-828889

[6] Schnitzler, F., Fidder, H., Ferrante, M., Noman, M., Arijs, I., Van Assche, G., Hoffman, I., Van Steen, K., Vermeire, S. and Rutgeerts, P. (2009) Long-Term Outcome of Treatment with Infliximab in 614 Patients with Crohn's Disease: Results from a Single-Centre Cohort. Gut, 58, 492-500. http://dx.doi.org/10.1136/gut.2008.155812

[7] O’Donnell, S., Murphy, S., Anwar, M.M., O’Sullivan, M., Breslin, N., O’Connor, H.J., Ryan, B.M. and O’Morain, C.A. (2011) Safety of Infliximab in 10 Years of Clinical Practice. European Journal of Gastroenterology \& Hepatology, 23, 603-606. http://dx.doi.org/10.1097/MEG.0b013e3283479125

[8] Hudesman, D., Lichtiger, S. and Sands, B. (2013) Risk of Extraintestinal Solid Cancer with Anti-TNF Therapy in Adults with Inflammatory Bowel Disease: Review of the Literature. Inflammatory Bowel Diseases, 19, 644-649. http://dx.doi.org/10.1097/MIB.0b013e318280ebbd

[9] Lust, M. and Travis, S. (2009) Is Anti-TNF Therapy Always Prohibited in Patients with Inflammatory Bowel Disease and Previous Malignancy? Practical Gastroenterology. Inflammatory Bowel Disease.

[10] Rojas-Feria, M., Castro, M., Suárez, E., Ampuero, J. and Romero-Gómez, M. (2013) Hepatobiliary Manifestations in Inflammatory Bowel Disease: The Gut, the Drugs and the Liver. World Journal of Gastroenterology, 19, 7327-7340. http://dx.doi.org/10.3748/wjg.v19.i42.7327

[11] Pedersen, N., Duricova, D., Elkjaer, M., Gamborg, M., Munkholm, P. and Jess, T. (2010) Risk of Extra-Intestinal Cancer in Inflammatory Bowel Disease: Meta-Analysis of Population-Based Cohort Studies. American Journal of Gastroenterology, 105, 1480-1487. http://dx.doi.org/10.1038/ajg.2009.760

[12] Erichsen, R., Jepsen, P., Vilstrup, H., Ekbom, A. and Sørensen, H.T. (2009) Incidence and Prognosis of Cholangiocar- 
cinoma in Danish Patients with and without Inflammatory Bowel Disease: A National Cohort Study, 1978-2003. European Journal of Epidemiology, 24, 513-520. http://dx.doi.org/10.1007/s10654-009-9365-4

[13] Biancone, L., Orlando, A., Kohn, A., Colombo, E., Sostegni, R., Angelucci, E., Rizzello, F., Castiglione, F., Benazzato, L., Papi, C., Meucci, G., Riegler, G., Petruzziello, C., Mocciaro, F., Geremia, A., Calabrese, E., Cottone, M. and Pallone, F. (2006) Infliximab and Newly Diagnosed Neoplasia in Crohn’s Disease: A Multicentre Matched Pair Study. Gut, 55, 228-233. http://dx.doi.org/10.1136/gut.2005.075937

[14] Berman, M.D., Falchuk, K.R. and Trey, C. (1980) Carcinoma of the Biliary Tree Complicating Crohn’s Disease. Digestive Diseases and Sciences, 25, 795-797. http://dx.doi.org/10.1007/BF01345302

[15] Krause, J.R., Ayuyang, H.Q. and Ellis, L.D. (1985) Occurrence of Three Cases of Carcinoma in Individuals with Crohn's Disease Treated with Metronidazole. American Journal of Gastroenterology, 80, 978-982.

[16] Altaee, M.Y., Johnson, P.J., Farrant, J.M. and Williams, R. (1991) Etiologic and Clinical Characteristics of Peripheral and Hilar Cholangiocarcinoma. Cancer, 68, 2051-2055. http://dx.doi.org/10.1002/1097-0142(19911101)68:9<2051::AID-CNCR2820680934>3.0.CO;2-M

[17] Choi, P.M., Nugent, F.W., Zelig, M.P., Munson, J.L. and Schoetz Jr., D.J. (1994) Cholangiocarcinoma and Crohn’s Disease. Digestive Diseases and Sciences, 39, 667-670. http://dx.doi.org/10.1007/BF02088359 
Scientific Research Publishing (SCIRP) is one of the largest Open Access journal publishers. It is currently publishing more than 200 open access, online, peer-reviewed journals covering a wide range of academic disciplines. SCIRP serves the worldwide academic communities and contributes to the progress and application of science with its publication.

Other selected journals from SCIRP are listed as below. Submit your manuscript to us via either submit@scirp.org or Online Submission Portal.
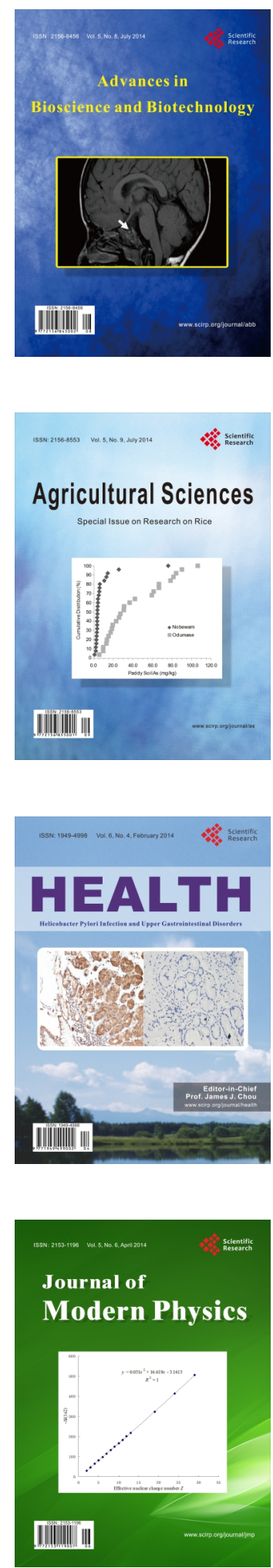
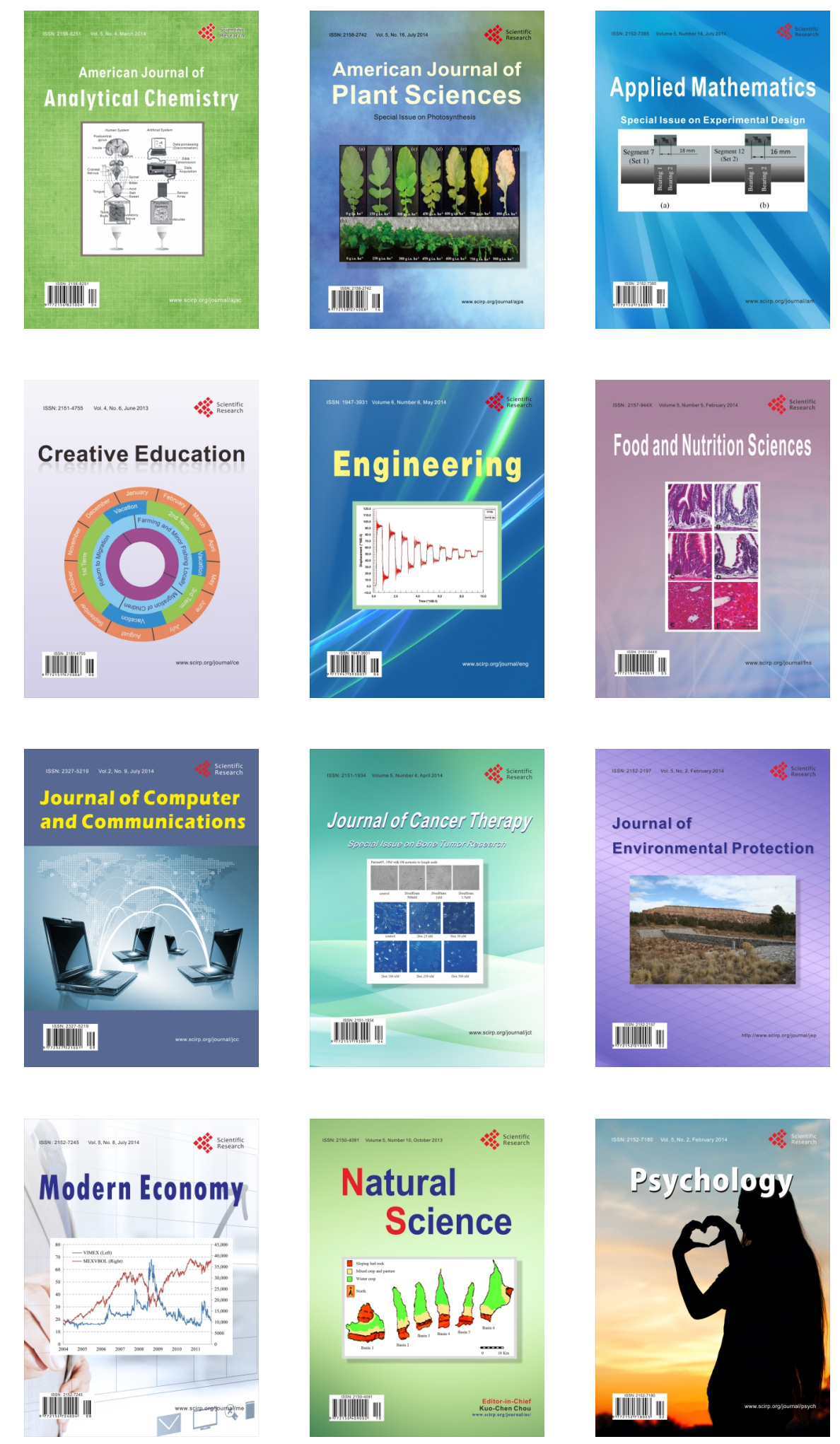